\title{
Prospects for exploration of hydrogen fields in riftogene structures of platforms (the case of the Dnieper-Donets Aulacogene) ${ }^{*}$
}

\author{
V.Shestopalov ${ }^{1,2}$, O. Lukin ${ }^{2}$, V. Starostenko ${ }^{3}$, O. Ponomarenko ${ }^{4}$, \\ T. Tsvetkova ${ }^{3}$, I. Koliabina ${ }^{2}$, O. Makarenko' ${ }^{1}$, O. Usenko ${ }^{3}$, O. Rud ${ }^{5}$, \\ A. Onoprienko ${ }^{6}$, V. Saprykin ${ }^{1}$, R. Vardapelian ${ }^{7}, 2021$ \\ ${ }^{1}$ Radioenvironmental Centre of the National Academy \\ of Sciences of Ukraine, Kiev, Ukraine \\ ${ }^{2}$ Institute of Geological Sciences of the National Academy \\ of Sciences of Ukraine, Kiev, Ukraine \\ ${ }^{3}$ S. I. Subbotin Institute of Geophysics of the National Academy \\ of Sciences of Ukraine, Kiev, Ukraine \\ ${ }^{4}$ M. P. Semenenko Institute of Geochemistry, Mineralogy and Ore Formation \\ of the National Academy of Sciences of Ukraine, Kyiv, Ukraine \\ ${ }^{5}$ G. V. Kurdyumov Institute of Metal Physics of the National Academy \\ of Sciences of Ukraine, Kiev, Ukraine \\ ${ }^{6}$ NDI Foundation, Kiev, Ukraine \\ ${ }^{7}$ European Centre for Knowledge and Technology Transfer, Brussels, Belgium \\ Received 25 August 2021
}

This paper shows the prospect to find industrial-scale hydrogen accumulations in riftogenic structures of platforms using the example of the Dnieper-Donets Aulacogene, located in the southern part of the East European Platform. Within the Dnieper-Donets Depression, geological and geophysical methods indicate a significant number of deep faults and ring structures of volcanogenic and explosive origin promising increased hydrogen content. Possible locations of the most propitious areas of hydrogen concentration are associated with faults in rift systems and their nearest margins, as well as with explosive and volcanogenic ring structures with signs of modern activation. At a fine-grained level, the prospectivity of the area is determined not only by the specified structural relationship, but also by the set of geophysical characteristics (thermal, seismic, gravity, electrical conductivity, magnetic) and the corresponding geological and hydrogeological parameters. Areas for further more detailed investigations within the Sribne and other ring structures, Southern Near-Edge Fault, Northern Near-Edge Fault were identified based on the data on geological and geophysical materials, satellite images, and field work. We defined high-priority and low-priority territories. Areas for initial investigations using satellite images, gas sampling (hydrogen, helium, methane, etc.), primary geophysical surveys (with evaluation of intermediate reservoirs and cap rocks) were identified. The primary results can be used to plan pilot shallow drilling and wells sampling. The areas for priority deeper drilling and sampling are selected by the sum of results obtained and data comparison. The paper presents the results obtained $30 \mathrm{~km}$ east of Kyiv as an example of field assessment of $\mathrm{H}_{2}$ degassing in a local depression. The results show that hydrogen concentrations at depths of 0.45 to $1.5 \mathrm{~m}$ are near zero outside the local depression. The maximum values of $\mathrm{H}_{2}$ concentration (up to 3300 ppm $1.5 \mathrm{~m}$ deep) are characteristic of the point inside the depression.

Key words: deep geological hydrogen, hydrocarbons, ring structures, rift, Sribne structure, hydrogen degassing, hydrogen deposits.

\footnotetext{
* The article is based on a report that was adopted and presented at I Natural Hydrogen Worldwide Summit (H-NAT 2021) in Paris (France) on June 2, 2021.
} 
Introduction. In this paper, using the example of the Dnieper-Donets Depression, (DDD), located in the southern part of the East European Platform and originated and developed in the Proterozoic and early Paleozoic as a typical rift, we would like to show the promise of such structures to discover elevated concentrations of native hydrogen (Fig. 1).

Although in the former USSR, geological hydrogen has been studied in various structures, at various depths, and of various genesis for a long time, and was first summarized in the English-language publication [Zgonnik, 2020], the most thorough studies of hydrogen in the Earth interior of individual regions and specific genetic types have been done in recent decades [Shestopalov, 2020].

Currently, two groups of hypotheses for the origin of hydrogen in the Earth's interior are considered in the world: the generation of secondary hydrogen in the Earth's crust and upper mantle, and the presence of primary hydrogen, which is initially concentrated in the core and lower mantle. The occurrence of secondary hydrogen is confirmed by numerous results of theoretical, field and experimental studies [Moody, 1976; Neal, Stanger, 1983; Vovk, 1987; Kelley et al., 2001; Klein et al., 2009; McCollom, Bach, 2009; Malvoisin et al., 2012; Sherwood Lollar et al., 2014; McCollom et al., 2016; Tian et al., 2016; Warr et al., 2019; Donze et al., 2020 etc.]. In particular, a large number of papers have shown that hydrogen can be generated by water interaction with minerals in mafic and ultramafic rocks (including serpentinisation of olivine) as well as by magmatic processes altering the upper mantle and crustal rocks [Sleep et al., 2004; Proskurowski et al., 2006; Seyfried et al., 2007; McCollom, Bach, 2009; Russel et al., 2010; Portnov, 2010; Belov, 2011; Hellevang et al., 2011; Mayhew et al., 2013; Sramek, 2013; McCollom, Seewald, 2013; Wang et al., 2014; Holm et al., 2015; Konn et al., 2015; Worman et al., 2016; Canovas et al., 2017; Huang et al., 2017; Malvoisin et al., 2017; Klein et al., 2019; Leong, 2020 etc.]. Another hypothesis, very common and highlighted in the scientific literature, is the formation of hydrogen by water radiolysis [Vovk, 1987; Dey et al.,
1990; Lin et al., 2005; Blair, 2007; Sherwood Lollar et al., 2014; Turkeet al., 2015; Dzaugis et al., 2016; Parnell, 2017; Warr et al., 2019 etc.]. Hydrolysis of minerals is also considered a source of hydrogen [Molchanov, 1981; Sherwood Lollar et al., 2014; Warr et al., 2019 etc.]. The possibility of biological generation and consumption of hydrogen [Chapelle et al., 2002; Takai et al., 2004; Lin et al., 2005; Russel et al., 2010; Parkes et al., 2011; McCollom, Seewald, 2013; Sukhanova et al., 2013; Polyanskaya, 2014; Wang et al., 2014; Konn et al., 2015; Chakmazyan, 2016; Dzaugis et al., 2016; Parnell, 2017 etc.] as well as its migration and formation in fault zones is widely considered [Wakita et al., 1980; Sugisaki et al., 1980; Jones, Pirkle, 1981; Ware et al., 1984; Sato et al., 1986; Su et al., 1992; Zhou et al., 2010 etc.].

The assumed occurrence of primary hydrogen was substantiated in a number of theoretical studies [Kronig et al.,1946; Stevenson, 1977; Larin, 1993, 2005; Semenenko, 1990; Marakushev, 1999; Rumyantsev, 2016 etc.], and was supported by specific studies of manifestations of degassing and migration of primary hydrogen [Letnikov, 2001, 2015; Syvorotkin, 2002; Gilat, Vol, 2005, 2012; Walshe, 2006; Gufeld, 2012, 2013; Murphy, 2016; Ikuta et al., 2019 etc.]. In particular, the results obtained by our research group [Shestopalov, Koliabina, 2019; Shestopalov et al., 2021], indicate the theoretical possibility of hydrogen penetration into olivine-bearing rocks from beneath (coming from the mantle), followed by formation of water and the initiation of serpentinization with additional hydrogen release. Based on the results obtained, serpentinization of olivine with hydrogen release, determined previously in many studies, can be considered the second phase of the whole process. The first phase consists of deep hydrogen penetration into olivine and water formation.

In support of this version of hydrogen primary generation, we provide the results of the application of seismic tomography to study processes in the mantle. According to the developed method for solving the inverse multidimensional problem of seismic kinematics, a three-dimensional velocity model of the mantle was obtained (Fig. 2). The re- 


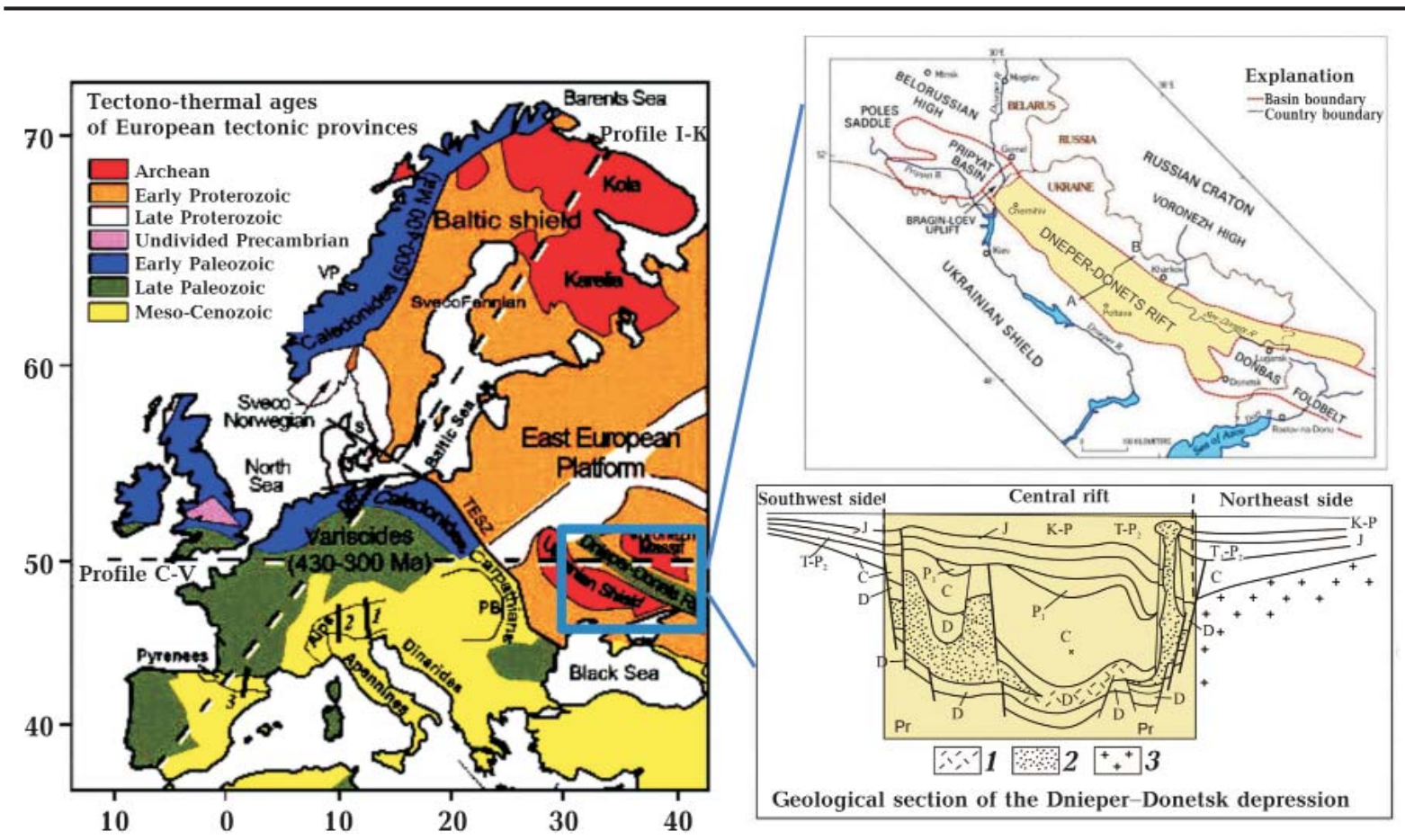

Fig. 1. Map and geological section of the Dnieper-Donets Aulacogen: 1 - volcanogenic formations, 2 - salts, 3 - Precambrian basement.

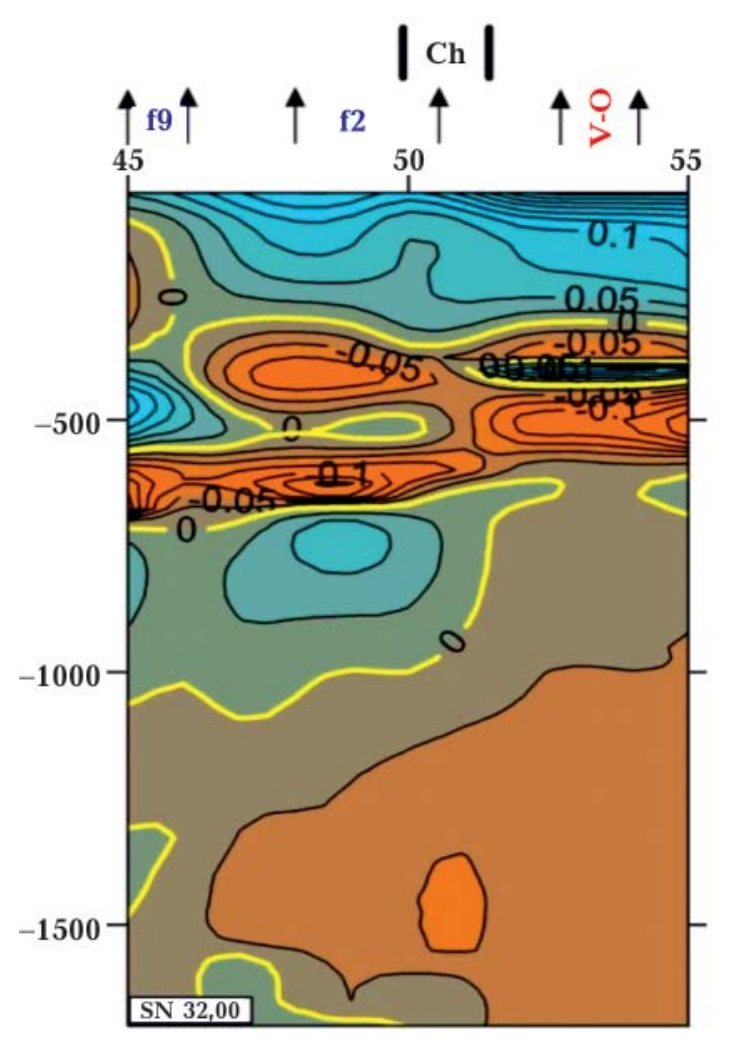

Fig. 2. Mantle plumes (V-O) and mantle superdeep fluid flows (f9, f2) from the three-dimensional P-velocity model of the mantle to a depth of $1700 \mathrm{~km}$. Ch - Chernihiv block of the Dnieper Donets Rift.

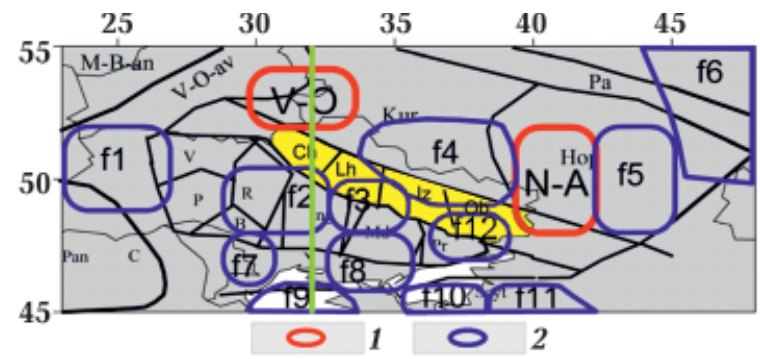

Fig. 3. Mantle plumes and superdeep mantle fluid flows from the three-dimensional P-velocity model of the mantle: 1 - plumes (V-O — Volyn-Orsha, N-A - North-Azov); 2 - superdeep fluid flows (f1-f12). Dnieper-Donets Rift is shown in yellow, the modelling profile (see Fig. 2) - in green.

vealed location of zones of superdeep fluid activation in the mantle indicates their relationship with the existence of oil-and-gas and probably hydrogen accumulations in the Dnieper-Donets Depression. Dr. Tatiana Tsvetkova and her colleagues [Tsvetkova et al., 2017,2020 ] have shown that not only plumes but also individual upward flows of deep fluid could be distinguished in the mantle beneath the platform. In particular, the Volyn-Orsha plume and four fluid flows (f2, f3, f4, f12) were distinguished in the vicinity of the DnieperDonets Rift (Fig. 3). 


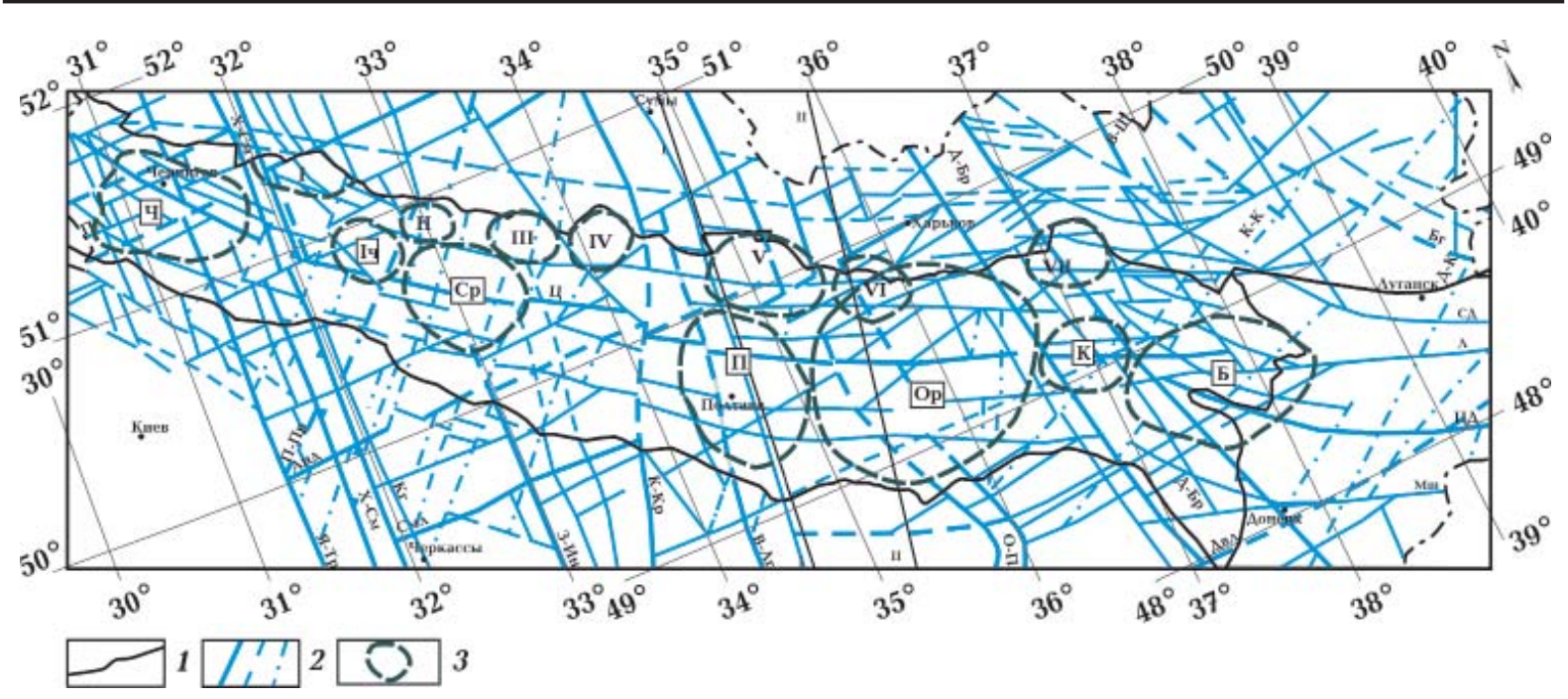

Fig. 4. Scheme of fault tectonics of the consolidated crust within the Dnieper-Donets Aulacogene [Modified from Starostenko et al., 2015] and location of ring structures within the Dnieper-Donets Rift: 1 - rift boundary; 2 faults; 3 - ring structures (letters in squares) (Ch — Chernihiv, Ich — Ichnyanska, Sr — Sribne, P — Poltava, Or - Orchitska, K - Komishevahska, B - Bakhmutska); ring structures of the northern near-edge part [Modified from Pashova et al., 2013] (I — Zagorevska, II — Dmytrivska, III — Romenska, IV — Synyavska, V — Parkhomenska, VI - Valkivska, VII - Brigadyrivska).

Along with the diffusive spreading of hydrogen in the rock mass, a relatively anomalous, often streamline migration of hydrogen in fault zones and fractures is detected. This fault-directed pathway of anomalous hydrogen migration, regardless of its origin, is the migration path of maximum concentration and density of the $\mathrm{H}_{2}$ fluid.

Results and discussion. Within the Dnieper-Donets Depression, the geologicalgeophysical methods distinguish a significant number of deep faults and ring structures of volcanogenic and explosive origin, which are of interest to discover the increased hydrogen accumulations. Possible locations of the most promising zones of hydrogen concentration in continental platform conditions are confined to faults in rift systems and their nearest fringe, as well as to explosion and volcanogenic ring structures with signs of modern activation (Fig. 4). The prospectivity of such area is determined by research and analysis of a set of geophysical characteristics (thermal, seismic, gravity, electrical conductivity, magnetic) and the corresponding geological and hydrogeological parameters.

Among them, we singled out the most studied Sribne ring structure [Lukin, Shestopalov, 2021]. A large number of hydrocar- bon fields have been explored and exploited within it, and we have outlined areas that are promising for the study of hydrogen (Fig. 5).

Many hydrocarbon fields have been explored near and within the Sribne ring structure, which is an explosive ring structure of ancient origin that is periodically activated even in the modern period.

The partially detected and supposed pulsatile nature of hydrogen degassing causes intermediate temporary accumulation of hydrogen in formations covered with low-permeable cap rocks, which impede hydrogen degassing, though cannot fully prevent it. Apart from dense igneous rocks (like dolerites in Mali), such low-permeable cap rocks may be formed by thick beds of rock salt at depths of $1-2 \mathrm{~km}$, hydrophilic clay, and intrusive rocks not subjected to metamorphism, etc.

Understanding of the hydrocarbon fields formation and established modern recharging of many of them suggest that their occurrence and maintenance of the certain reserve level is associated with modern activation processes, characterised by intensive migration of hydrogen, which determines the hydrogenation of carbonaceous components. Therefore, oil and gas wells contain the residual hydrogen 


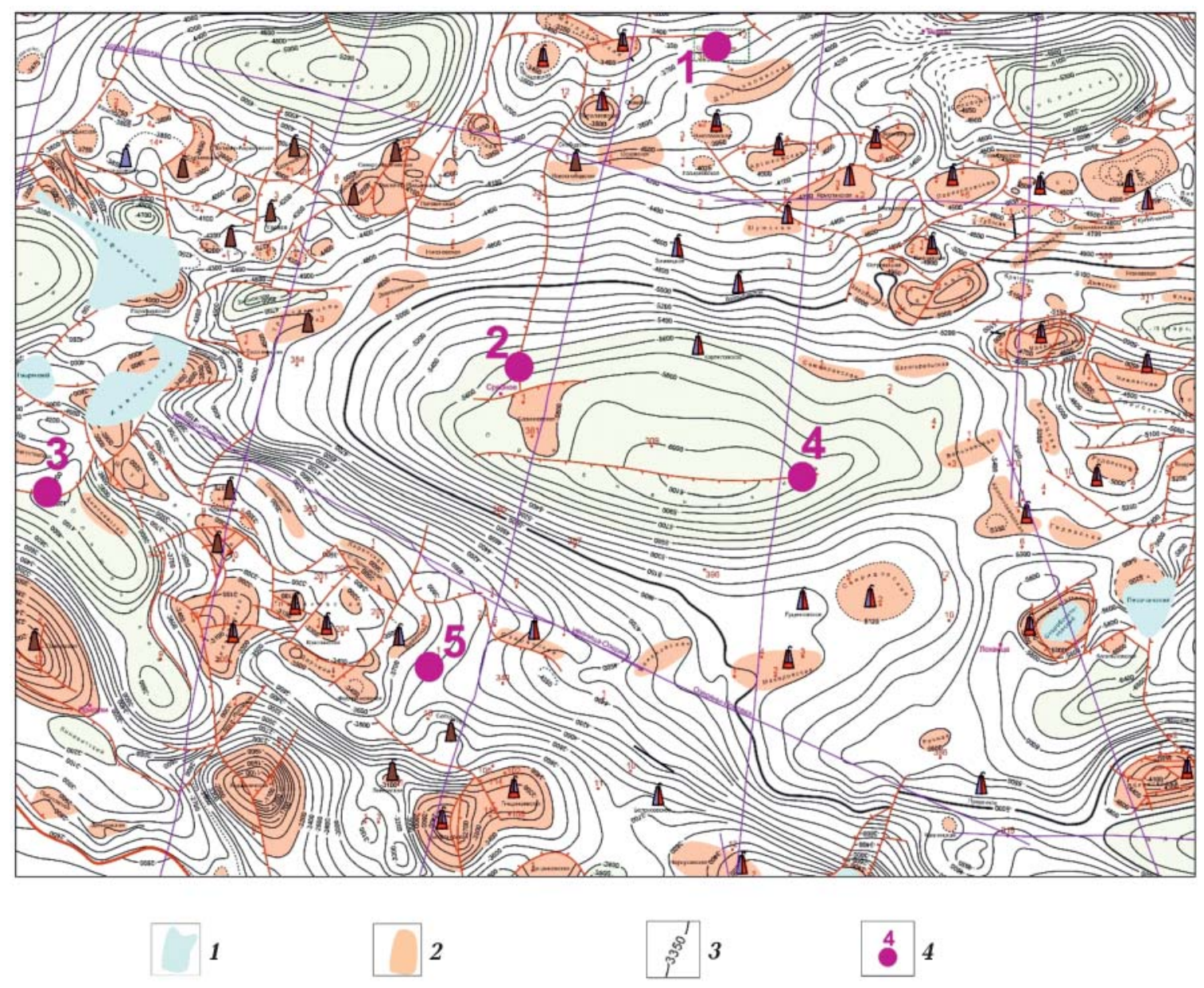

Fig. 5. Sribne ring structure and the areas identified as promising for studying the potential of hydrogen degassing: 1 - salt intrusive; 2 - hydrocarbon deposits; 3 - absolute levels of the base of the Carboniferous (carbonic) sediments; 4 - sites of high-priority investigation.

unconsumed in hydrocarbon formation. However, besides zones of hydrocarbon accumulation and hydrogen consumption for their formation, there may exist zones with conditions of minimising the carbon concentration in geological structure and, consequently, increasing the concentration of uninvolved hydrogen. To select areas located between or beyond hydrocarbon fields (both well-known, as well as not yet discovered), the analysis of local depressions distribution should be used, in which anomalies of hydrogen concentrations are identified by subsoil measurements (see [Larin et al., 2015; Zgonnik et al., 2015, etc.]).

In the Dnieper-Donets Depression, a variety of local depressions have been decoded from satellite images. The depressions that form well-defined linear chains and ring structures indicating different stages of degassing are well distinguished among them (Fig. 6).

As an example of field work to assess $\mathrm{H}_{2}$ degassing in a local depression, we present the results obtained $30 \mathrm{~km}$ east of Kyiv. The graph clearly shows that outside the local depression, hydrogen concentrations at depths of 0.45 to $1.5 \mathrm{~m}$ are close to zero. The maximum values of the $\mathrm{H}_{2}$ concentration are typical for point 5 near the edge of the depression and they reach $3300 \mathrm{ppm}$ at the depth of $1.5 \mathrm{~m}$ (Fig. 7).

The space images were used to identify and quantify the local depressions of the DnieperDonets Aulacogene (Fig. 8). About 400,000 local depressions were identified, clustering 


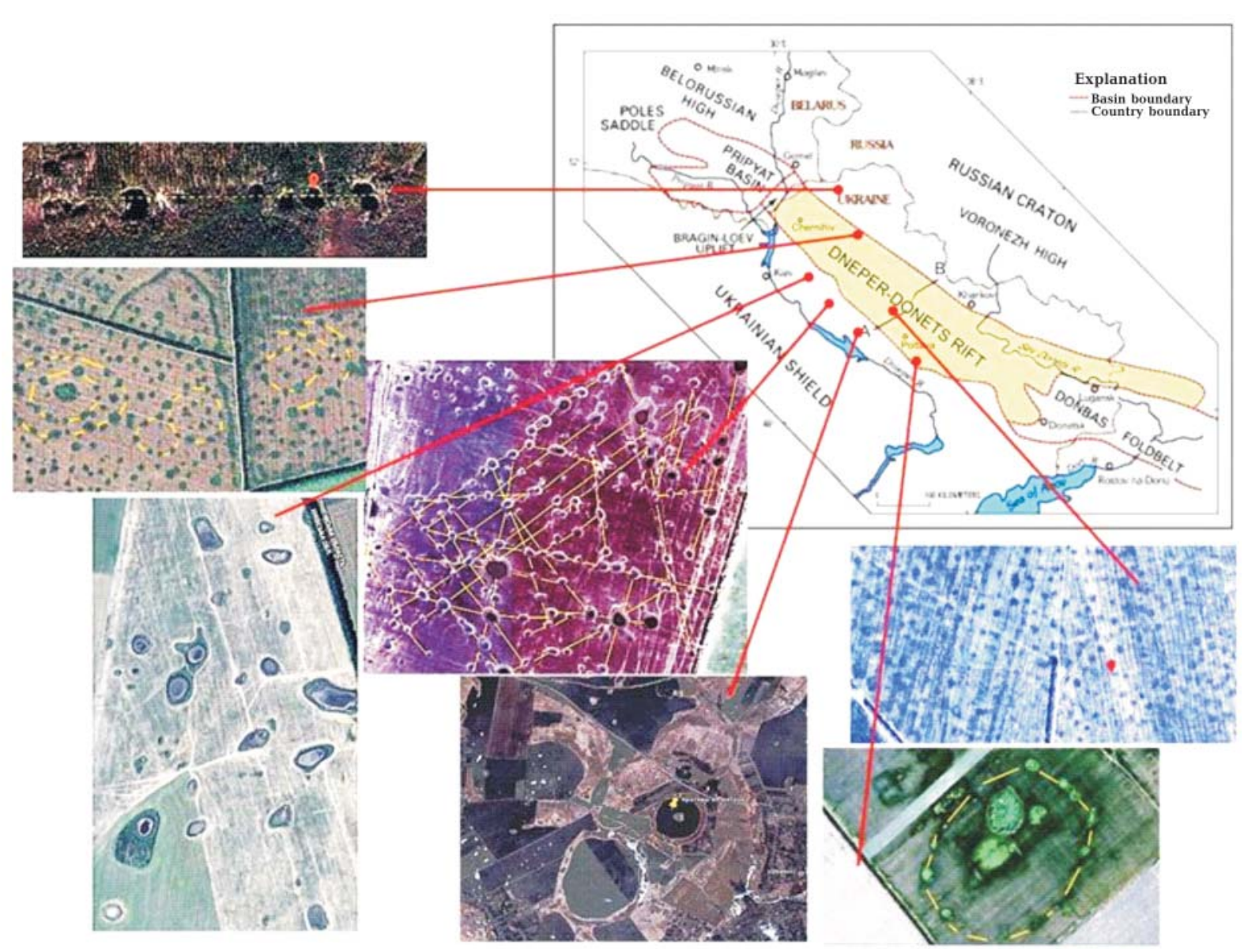

Fig. 6. Variety of local depressions within the Dnieper-Donets Aulacogene.

into linearly elongated lines and spots (shown in white in the Fig. 8). The thickening maxima of these depressions form linearly elongated lineaments (shown in red in the Fig. 8), which coincide well with modern geodynamic areas and some faults identified by other methods. These and other results indicate a clear linkage of local depressions distribution maxima to the fault zones of recent activation, to the areas of highly fractured hard rocks, and to zones of loose rocks decompression.

The clusters of local depressions are mostly located outside the contours of hydrocarbon fields. Most of local depressions are located in the zone of the Southern Near-Edge Fault and the southern slope of the basement. No hydrocarbon fields are discovered in this area. Local depressions are associated with main geodynamic zones and, occasionally, with lo$\mathrm{cal}$ fracturing of sedimentary rocks in these zones. Individual measurements of subsoil hydrogen in these depressions show values of up to $11800 \mathrm{ppm}$. Presumably, the conditions within the area of Southern Near-Edge Fault and the southern slope of the basement are quite similar in setting to those in Mali. In Mali the hydrogen field is located in the near-slope part of the basement, while in DDD, many local depressions resulted from degassing are concentrated in the southern near-slope part of the basement. The main oil-and-gas bearing region is located to the north of Mali, in the deeper part of the trough, while in DDD it is located north of the abovementioned local depressions, in the central part of the graben.

Noteworthy results were obtained in the area of the Northern Near-edge Fault of the mantle origin within the Dnieper-Donets Graben (Fig. 9). A large number of hydrocarbon fields are concentrated near this fault (marked in yellow on the Fig. 9). Relatively maximum 


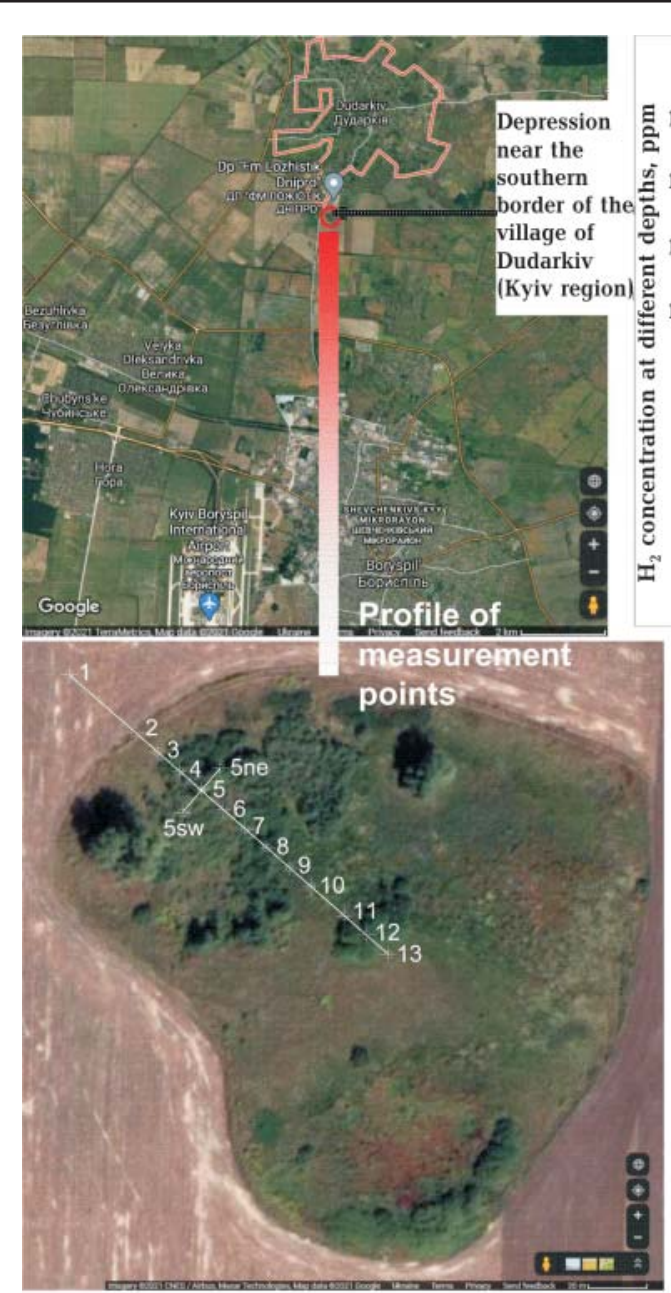

Fig. 7. Results of $\mathrm{H}_{2}$ degassing measurements in a local depression $30 \mathrm{~km}$ east of Kyiv.
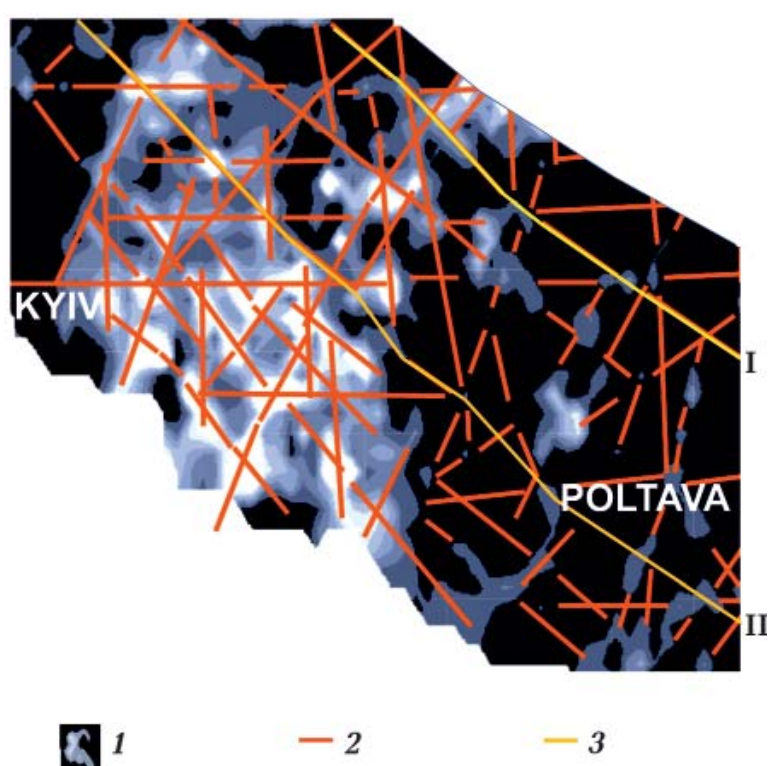

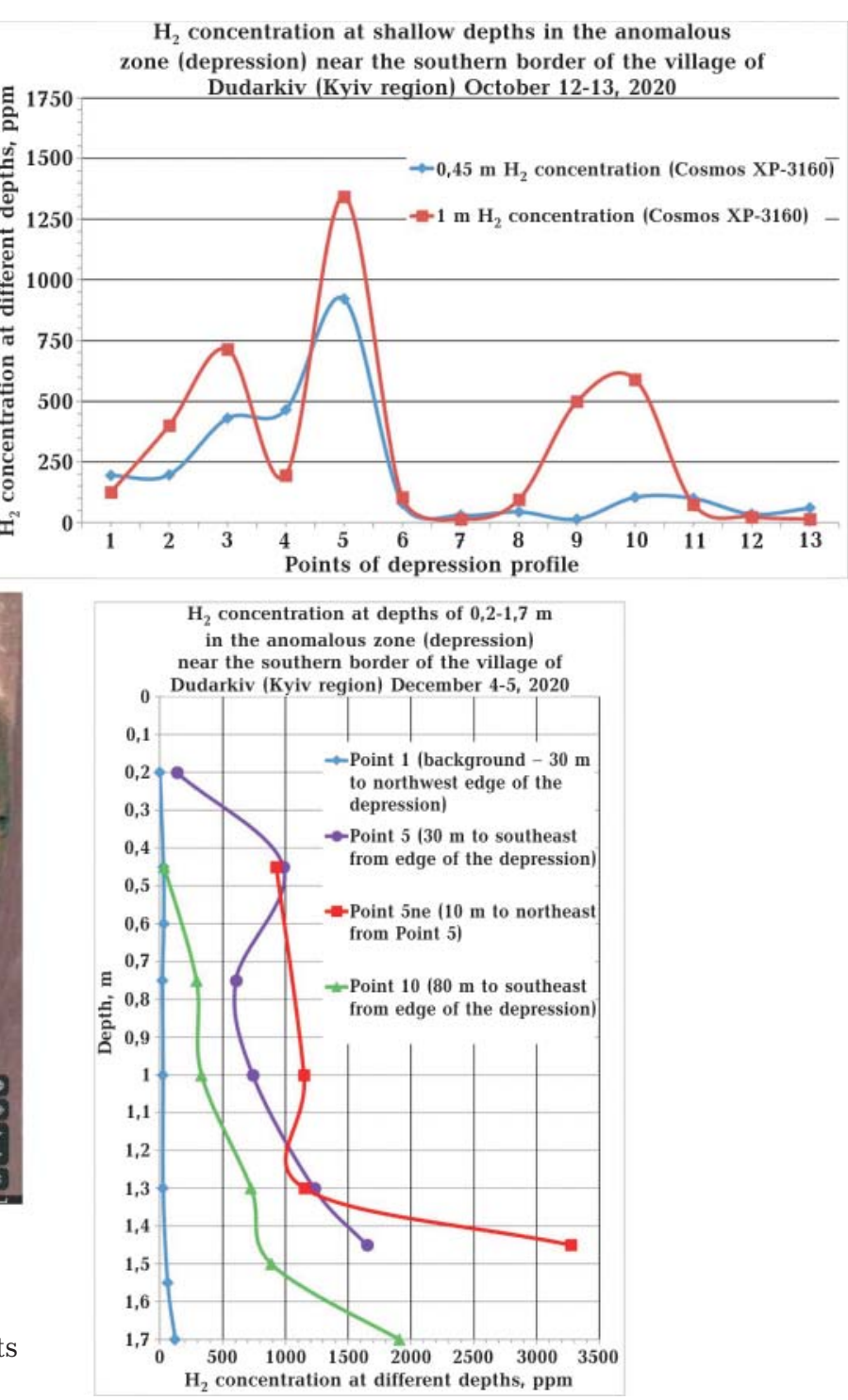

concentrations of local depressions (marked in red on the Fig. 9) allow us to assume the predominant concentration of molecular $\mathrm{H}_{2}$ clusters outside the hydrocarbon clusters, which are the product of the hydrogen influencing the carbonaceous components of the geological environment.

There are no hydrocarbons in the zone of the Southern Near-Edge Fault (see Fig. 6), but this area, including the southern slope of the Dnieper-Donets Depression, contains

$\Leftarrow \mid$ Fig. 8. Spread of local depressions in the DnieperDonets Aulakogene: 1 - shades of white - the relative density of local depressions per $\mathrm{km}^{2} ; 2$ - lineaments at the maximum density of local depressions; 3 - schematic position of the near-edge faults (I — Northern, II — Southern). 


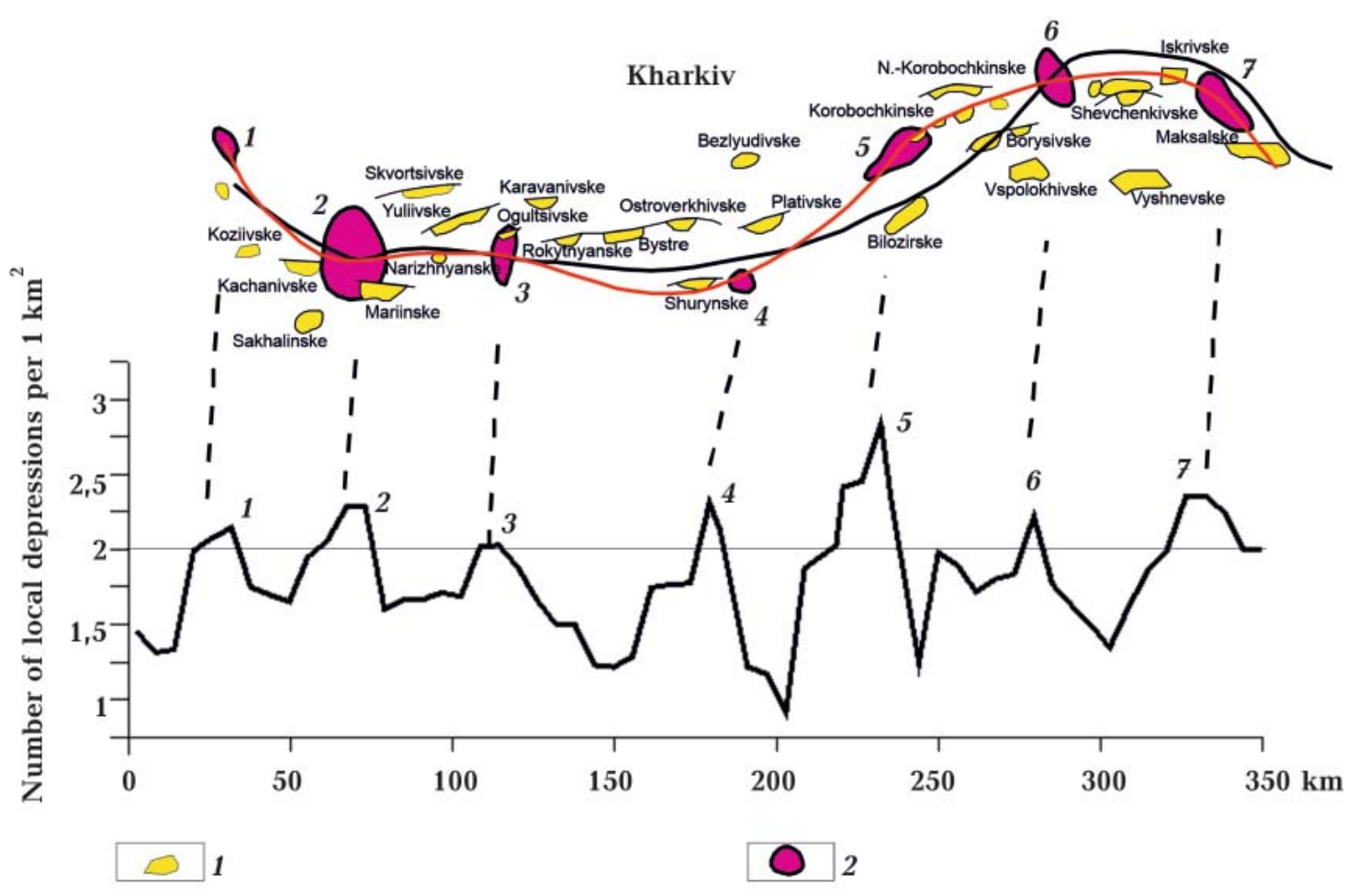

Fig. 9. Discrepancy between the locations of hydrocarbon fields and locations of maximum accumulations of local depressions: 1 - hydrocarbons, 2 - local depressions maxima.

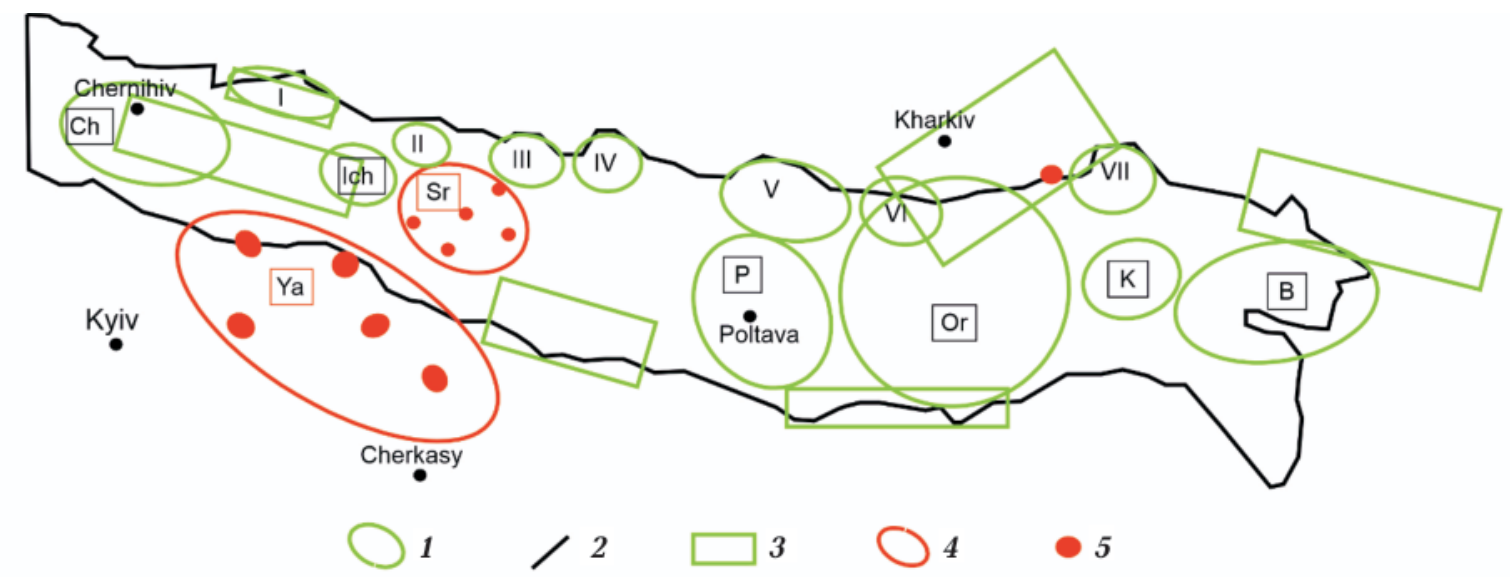

Fig. 10. Areas for further more detailed work: 1 - ring structures; 2 - rift boundary; 3 - areas for further studies, based on geophysical data; 4 - first priority areas for studies; 5 - first priority sites for studies.

the greatest density of local depressions. The result can be interpreted as evidence of significant upward degassing in this area.

Based on the results of the study of geological and geophysical materials, space images and field work, the territories for further more detailed work were allocated within (Fig. 10):

- Sribne and other ring structures,

- Southern Near-Edge Fault,
- Northern Near-Edge Fault.

In this case, the areas for the first-priority study (highlighted in red) and for secondpriority study were identified. Within these areas sites were indicated (red dots) for initial investigation using satellite images, gas sampling (hydrogen, helium, methane, etc.), primary geophysical surveys, with evaluation of intermediate reservoirs and cap rocks. And 
their results can be used to carry out shallow test drilling and sampling. According to the results obtained and data comparison, the sites for priority drilling and sampling to a greater depth will be selected.

Conclusions. Selection of preferred areas for detailed investigation should be based on a comprehensive analysis of available geophysical data, study of the geological section with the identification of potential reservoirs and possible low-permeable cap rocks, performing certain types of geophysical studies to specify geophysical characteristics, detailed interpretation of space images to study the features of local depressions and their clusters as well as gas geochemical studies. Based on results of all investigations the most promising areas are selected, as well as a scope of detailed geological-geophysical and gas-geochemical investigations determined. Upon analysis of all materials obtained, sites for exploratory drilling are selected and technical parameters specified.

The following factors provide confidence in the success of the exploration of the hydrogen reservoirs in the Dnieper-Donets Depression:

1. Rift systems in the platforms are characterized by deep activation of the geological environment within the Earth crust and upper mantle with active spreading of volcanogenic explosive ring structures originated in the Earth's deep interior under the action of fluids.

2. Rift systems are characterized by the development of faults originated in the mantle, often under tension stress, which have been active for a long geological time.

3. The high concentration of hydrocarbon fields in the Dnieper-Donets Rift (over 200 proven fields and significant prospects for their increase) indicates a considerable opening of the Earth's deep interior, which facilitates the upward migration of fluids.

4. Hydrocarbon fields within the rift show elevated helium concentrations (total and $\mathrm{He}_{3} / \mathrm{He}_{4}$ ratio), which also indicate the active connection of sedimentary cover with the Earth's deep interior (lower crust and upper mantle).

5. Geophysical surveys allow identifying areas of high electrical conductivity, thermal field anomalies (when measuring the convective component in fault zones), relative minima of the gravity field, etc., indicating the potential for significant hydrogen accumulations.

6. The investigations of the lower mantle also indicate the manifestation therein of deep upward migration of fluids in the zone of probable influence on the upper mantle beneath the Dnieper-Donets Aulacogene.

7. Detection from satellite images of local depressions concentration in the modern relief and finding their connection with faults indicate the active modern degassing of hydrogen.

8. Some wells drilled for hydrocarbon production have shown elevated hydrogen concentrations (up to $25-40 \%$ ).

9. The geological section contains rocks that can store and transmit hydrogen (reservoir rocks) as well as cap rocks that form a barrier above and partially prevent the free upward migration of hydrogen, thus contributing to its temporary accumulation in the reservoir rocks.

All this combined presents an optimistic outlook for the discovery of hydrogen fields in the Dnieper-Donets Aulacogene.

The arguments for the selection of priority areas are:

1. The Sribne depression was selected because it represents deep volcanogenic-explosive ring structure that has manifested activation at all major stages of its development, including the modern one.

2. The geology of this area is the most extensively studied. It is characterized by the occurrence of a large number of proven hydrocarbon fields confined to the Upper Carboniferous and Permian deposits and found at depths ranging from 1.2 to 6.5 kilometers.

3. Locally, the elevated helium concentrations (up to $1.78 \mathrm{wt} \%$ ) were detected in the boreholes.

4. Hydrogen degassing is confirmed by a large number of local depressions related to disjunctive dislocations.

5. Geological section in this area is characterized by occurrence of reservoir rocks 
and good cap rocks - relatively impermeable rocks involving salt formations with low permeability.

6. The area including the Southern NearEdge Fault and the southern slope of the Dnieper-Donets Depression was selected because it combines a well-developed network of deep faults and their intersections with the highest density of local depressions, their lin-

\section{References}

Belov, S. V. (2011). Hydrogen degassing of the planet: analysis of volcanic structures. Oko planet. Retrieved from https://oko-planet.su/ phenomen/phenomenscience/93242-vodorodnaya-degazaciya-planety-analiz-vulkanicheskih-struktur.html (in Russian).

Blair, C. C., D'Hondt, S., Spivack, A. J., \& Kingsley, R. H. (2007). Radiolytic hydrogen and microbial respiration in subsurface sediments. As trobiology, 7, 951—970.https://doi.org/10.1089/ ast.2007.0150.

Canovas III, P. A., Hoehler, T., \& Shock, E. L. (2017). Geochemical bioenergetics during low- temperature serpentinization: An example from the Samailophiolite, Sultanate of Oman. JGR Biogeosciences, 122, 1821-1847. https:// doi.org/10.1002/2017JG003825.

Chakmazyan, K. V. (2016). Changes in microbial biomass structure of soils under conditions of natural accumulation and emission of hydrogen: Candidate's thesis. Moscow, 113 p. (in Russian).

Chapelle, F., O'Neill, K., Bradley, P. M., VletlK', B. A., Ciufo, S. A., Knobel, L. L., \& Lovley, D. R. (2002). A hydrogen-based subsurface microbial community dominated by methanogens. Nature, 415, 312-315. https://doi. org/10.1038/415312a.

Dzaugis, M. E., Spivack, A. J., Dunlea, A. G., Murray, R. W., \& D'Hondt, S. (2016). Radiolytic hydrogen production in the subseafloor basaltic aquifer. Frontiers in Microbiology, 7, 76. https:// doi.org/10.3389/fmicb.2016.00076.

Dey, G. R., Kishore, K., Moorthy, P. N., Ramshesh, V., Srivasteva, S. B., \& Thomas, V. G. (1990). Water radiolysis at high temperatures and pressures. Bombay: Bhabha Atomic Research Centre, $27 \mathrm{p}$. ear and nodal concentrations, indicating the anomalous degassing in this area.

7. The area of concentrated degassing in the Dnieper-Donets Depression resembles the situation in Mali, where the hydrogen field is located in the craton slope, while the oil and gas promising areas are concentrated further north, in the central parts of the trough - in southern Algeria and northern Mali.

Donze, F.-V., Truche, L., ShekariNamin, P., Lefeuvre, N., \& Bazarkina, E. F. (2020).Migration of Natural Hydrogen from Deep-Seated Sources in the São Francisco Basin, Brazil. Geosciences, 10, 346. https://doi.org/10.3390/geosciences10090346.

Gilat, A. L., \& Vol, A. (2005). Primordial hydro-genhelium degassing, an overlooked major energy source for internal terrestrial processes. HAIT Journal of Science and Engineering B, 2(1-2), 125-167.

Gilat, A. L., \& Vol, A. (2012).Degassing of primordial hydrogen and helium as the major energy source for internal terrestrial processes. Geoscience Frontiers, 3(6), 911-921.https://doi. org/10.1016/j.gsf.2012.03.009.

Gufeld, I. L. (2012).Geological consequences of amorphization of the lithosphere and upper mantle structures, caused by hydrogen degassing. Geodinamika i tektonofizika, 3(4), 417-435. https://doi.org/10.5800/GT-2012-34-0083 (in Russian).

Gufeld, I. L. (2013). On deep degassing and structure of lithosphere and upper mantle. Glubinnaya neft, 1(2), 171-188 (in Russian).

Hellevang, H., Huang, S., \& Thorseth, I. H. (2011). The Potential for Low-Temperature Abiotic Hydrogen Generation and a Hydrogen-Driven Deep Biosphere. Astrobiology, 11(7), 711-724. http://doi.org/10.1089/ast.2010.0559.

Holm, N. G., Oze, C., Mousis, O., Waite, J. H., \& Guilbert-Lepoutre, A. (2015). Serpentinization and the formation of $\mathrm{H}_{2}$ and $\mathrm{CH}_{4}$ on celestial bodies (planets, moons, comets).Astrobiology, 15(7), 587-600. https://doi.org/10.1089/ast. 2014.1188 .

Huang, R., Lin, C., Sun, W., Ding, X., Zhan, W., 
\& Zhu, J. (2017). The production of iron oxide during peridotite serpentinization: Influence of pyroxene. Geoscience Frontiers, 8(6), 1311 1321. https://doi.org/10.1016/j.gsf.2017. 01.001.

Ikuta, D., Ohtani, E., Sano-Furakawa, A., Shibazaki, Y., Terasaki, H., Yuan, L., \& Hattori, T. (2019).Interstitial hydrogen atoms in facecentered cubic iron in the Earth's core. Scientific Reports, 9, 7108.https://doi.org/10.1038/ s41598-019-43601-z.

Jones, V. T., \& Pirkle, R. J. (1981). Helium and hydrogen soil gas anomalies associated with deep or active faults: Proc. of the 1981 American Chemical Society Annual Meeting, Atlanta, GA.

Kelley, D. S., Karson, J. A., Blackman, D. K., FruhGreen, G. L., Butterfield, D. A., Lilley, M. D., Olson, E. J., Schrenk, M. O., Roe, K. K., Lebon, G. T., \& Rivizzigno, P. (2001). An off-axis hydrothermal vent field near the Mid-Atlantic Ridge at 30ON. Nature, 412, 127-128. https:// doi.org/10.1038/35084000.

Klein, F., Bach, W., Jons, N., McCollom, T., Moskowitz, B., \& Berquo, T. (2009). Iron partitioning and hydrogen generation during serpentinization of abyssal peridotites from $15 \mathrm{~N}$ on the Mid Atlantic Ridge. Geochimica et Cosmochimica Acta, 73(22), 6868-6893. https://doi. org/10.1016/j.gca.2009.08.021.

Klein, F., Grozeva, N. G., \& Seewald, I. S. (2019), Abiotic methane synthesis and serpentinization in olivine - hosted fluid inclusions. Proc. of the National Academy of Sciences of the USA, 116(36), 17666-17672. Retrieved from www. pnas.org/cgi/doi/10.1073/pnas.1907871116.

Konn, C., Charlou, J. L., Holm, N. G., \& Mousis, O. (2015).The production of Methane, Hydrogen and Organic Compounds in Ultramafic Hosted Hydrothermal Vents of the Mid-Atlantic Ridge. Astrobiology, 15(5), 381-399. https:// doi.org/10.1089/ast.2014.1198.

Kronig, R., de Boer, J., \& Korringa, J. (1946). On the internal constitution of the Earth.Physica, 12(5), 245-256. https://doi.org/10.1016/S0031 -8914(46)80065-X.

Larin, V. N. (1993). Hydridic Earth: The New Geology of Our Primordially Hydrogen-rich Planet. Alberta: Polar Publishing, 247 p.

Larin, V. N. (2005). Our Earth (origin, composition, structure and evolution of primordially hydridic Earth). Moscow: Agar, 247 p. (in Russian).

Larin, N. V., Zgonnik, V., Rodina, S., Deville, E., Prinzhofer, A., \& Larin, V. N. (2015). Natural molecular hydrogen seepage associated with surficial, rounded depressions on the European Craton in Russia. Natural Resources Research, 24, 369-38. https://doi.org/10.1007/s11053014-9257-5.

Leong, J. A. M., \& Shock, E. L. (2020).Thermodynamic constraints on the geochemistry of low- temperature, continental, serpentinization-generated fluids. American Journal of Science, 320(3), 185-235. https://doi.org/10.2475/ 03.2020.01.

Letnikov, F. A. (2001). Ultradeep fluid systems of the Earth and problems of ore formation. Geologiya rudnykh mestorozhdeniy, 43(4), 291307 (in Russian).

Letnikov, F. A. (2015). Deep fluids of the continental lithosphere. Proceedings of the All-Russia conference «Fluid regime of endogenic processes in the continental lithosphere» (pp. 11-22). Irkutsk: Institute of the Earth's Crust SB RAS (in Russian).

Lin, Li-H., Hall, J., Lippmann-Pipke, J., Ward, J. A., Sherwood Lollar, B., DeFlaun, M., Rothmel, R., Moser, M., Gihring, T. M., Mislowack, B., \& Onstott, T. C. (2005). Radiolytic $\mathrm{H}_{2}$ in continental crust: Nuclear power for deep subsurface microbial communities. Geochemistry, Geophysics, Geosystems, 6(7), 3-13. https://doi. org/ 10.1029/2004GC000907.

Lukin, A. E., \& Shestopalov, V. M. (2021). Tectono-magmatogenering structures in zones of increased geodynamic instability as priority objects for exploration of hydrogen fields. Geofizicheskiy Zhurnal, 43(4), 3-43 (in Russian). https://doi.org/10.24028/gzh.v43i4.239953.

Malvoisin, B., Brunet, F., Carlut, J., Roumon, S., \& Cannat, M. (2012). Serpentinization of oceanic peridotites: 2. Kinetics and processes of San Carlos olivine hydrothermal alteration. Journal of Geophysical Research: Solid Earth, 117 , B04102.https://doi.org/10.1029/2011JB008842.

Malvoisin, B., Brantut, N., \& Kaczmarek, M. (2017). Control of serpentinisation rate by reaction-induced cracking. Earth and Planetary Science Letters, 476, 143-152. https://doi.org /10.1016/j.epsl.2017.07.042. 
Marakushev, A. A. (1999). Origin of the Earth and nature of its endogenous activity. Moscow: Nauka, 253 p. (in Russian).

Mayhew, L. E., Ellison, E. T., McCollom, T. M., Trainor, T. P., \& Templeton, A. S. (2013). Hydrogen generation from low-temperature water-rock reactions. Nature Geoscience, 6(6), 478-484. https://doi.org/10.1038/ngeo1825.

McCollom, T. M., \& Bach, W. (2009).Thermodynamic constraints on hydrogen generation during serpentinization of ultramafic rocks. Geochimica et Cosmochimica Acta , 73(3), 856875. https://doi.org/10.1016/j.gca.2008.10.032.

McCollom, T. M., \& Seewald, L. S. (2013). Serpentinites, hydrogen and life. Elements, 9(2), 129 134. https://doi.org/10.2113/gselements.9.2. 129.

McCollom, T. M., Klein, F., Robbins, M., Moskowitz, B., Berquo, T. S., Jons, N., Bach, W., \& Templeton, A. (2016). Temperature trends for reaction rates, hydrogen generation, and partitioning of iron during experimental serpentinization of olivine. Geochimica et Cos mochimica Acta, 181(15), 175-200. https://doi. org/10.1016/i.gca.2016.03.002.

Molchanov, V. I. (1981). Hydrogen generation in lithogenesis. Novosibirsk: Nauka, 142 p. (in Russian).

Moody, J. B. (1976). Serpentinization: a review. Lithos, 9(2), 125-138. https://doi.org/10.1016/ 0024-4937(76)90030-X.

Murphy, C. A. (2016). Hydrogen in the Earth's Core: Review of the Structural, Elastic and Thermodynamic Properties of Iron-Hydrogen Alloys. In Deep Earth: Physics and Chemistry of the Lower Mantle and Core (pp. 253-264). https:// doi.org/10.1002/9781118992487.ch20.

Neal, C., \& Stanger, G. (1983). Hydrogen generation from mantle source rocks in Oman. Earthand Planetary Science Letters, 66, 315-320. https://doi.org/10.1016/0012-821X(83)90144-9.

Parkes, R. J., Linnane, C. D., Webster, G., Sass, H., Weightman, A. J., Hornibrook, E. R. C., \& Horsfield, B. (2011). Prokaryotes stimulate mineral $\mathrm{H}_{2}$ formation for the deep biosphere and subsequent thermogenic activity. Geology, 39(3), 219_222. http://dx.doi.org/10.1130/G31598.1.

Parnell, J., \& Blamey, N. (2017).Global hydrogen reservoirs in basement and basins. Geochemical Transactions, 18(1). https://doi.org/10.1186/ s12932-017-0041-4.

Pashova, N. T., Krivosheya, V. M., Marina, N. V., Fedorchuk, N. I. (2013). Ring structures on the northern coastal zone of DDD - deep migration channels of explosives - analogues of "GAS HIMNEYS». Azov-Black Sea landfill for the study of geodynamics and fluid dynamic of oil and gas fields. Abstracts of the XI International Conference: “Crimea-2013», Simferopol (pp. 32-33).

Polyanskaya, L. M., Sukhanova, N. I., Chakmazyan, K. V., \& Zvyagintsev, D. G. (2014). Specific features of the structure of microbial biomass in soils of annular mesodepressions in Lipetsk and Volgograd oblasts. Eurasian Soil Science, 47(9), 903 -909. https://doi.org/10.1134/ S1064229314090105.

Portnov, A. V. (2010). Volcanoes - natural hydrogen fields. Promyshlennye vedomosti, (10 12). Retrieved from https://www.promved.ru/ articles/article.phtml?id=2015 (in Russian).

Proskurowski, G., Lilley, M. D., Kelley, D. S., \& Olson, E. J. (2006). Low temperature volatile production at the Lost City Hydrothermal Field, evidence from a hydrogen stable isotope geothermometer. Chemical Geology, 229, 331-343. https://doi.org/10.1016/i.chemgeo.2005.11.005.

Rumyantsev, V. N. (2016). Hydrogen in the Earth's outer core and its role in the deep Earth geodynamics. Geodynamics and Tectonophysics, 7(1), 119-135. https://doi.org/10.5800/GT-20 16-7-1-0200.

Russell, M. J., Hall, A. J., \& Martin, W. (2010). Serpentinization as a source of energy at the origin of life. Geobiology, 8(5), 355-371. https:// doi.org/10.1111/j.1472-4669.2010.00249.x.

Sato, M., Sutton, A. L., McGee, K. A., \& RusselRobinson, S. (1986). Monitoring of hydrogen along the San Andreas and Calaveras faults in central California in 1980-1984. Journal of Geophysical Research, 91(B12), 1315-1326. https:doi.org/10.1029/JB091iB12p12315.

Semenenko, N. P. (1990). Oxygen-hydrogen model of the Earth. Kiev: Naukova Dumka, 240 p. (in Russian).

Seyfried, W. E., Foustoukos, D. I., \& Qi, F. (2007). 
Redox evolution and mass transfer during serpentinization: An experimental and theoretical study at $200{ }^{\circ} \mathrm{C}$, 500 bar with implications for ultramafic-hosted hydrothermal systems at Mid-Ocean Ridges. Geochimica et Cosmochimica Acta , 71(15), 3872-3886. https://doi. org/10.1016/i.gca.2007.05.015.

Sherwood Lollar, B., Onstott, T., Lacrampe-Couloume, G., \& Ballentine, C. (2014). The contribution of the Precambrian continental lithosphere to global $\mathrm{H}_{2}$ production. Nature, 516, 379-382. https://doi.org/10.1038/nature14017.

Shestopalov, V. M. (2020). On geological hydrogen. Geophysical Journal, 42(6), 3-35. https://doi. org/10.24028/gzh.0203-3100.v42i6.2020.222278 (in Russian).

Shestopalov, V. M., Koliabina, I. L., Ponomarenko, O. M., Lukin, A. Ye., \& Rud, A. D. (2021). Thermodynamic assessment of the possibility of olivine interaction with deep-seated hydrogen. International Journal of Hydrogen Energy. https://doi.org/10.1016/j.ijhydene.2021.02.152.

Shestopalov, V. M., \& Kolyabina, I. L. (2019). Preliminary results of analysis of possibility for serpentinization of olivine in the absence of water: Abstracts of scientific conference «Achievements and development of geological science in Ukraine» (Vol. 1, pp. 120-121). Kyiv: Publ. of the Institute of Geochemistry, Mineralogy and Ore Formation (in Ukrainian).

Sleep, N. H., Meibom, A., Fridriksson, Th., Coleman, R. G., \& Bird, D. K. (2004). H2-rich fluids from serpentinization: geochemical and biotic implications. Proceedings of the National Academy of Sciences of the USA, 101(35), 818- 823. https://doi.org/10.1073/pnas.0405289101.

Šrámek, O., McDonough, W. F., Kite, E. S., Lekić, V., Dye, S. T., \& Zhong, S. (2013). Geophysical and geochemical constraints on geoneutrino fluxes from Earth's mantle. Earth and Planetary Science Letters, 361, 356-366. https://doi.org/10.1016/j.epsl.2012.11.001.

Starostenko, V. I., Janik, T., Yegorova, T., Farfuliak, L., Czuba, W., ظroda, P., Thybo, H., Artemieva, I., Sosson, M., Volfman, Yu., Kolomiyets, K., Lysynchuk, D., Omelchenko, V., Gryn, D., Guterch, A., Komminaho, K., Legostaeva, O., Tiira, T., \& Tolkunov, A. (2015). Seismic model of the crust and upper mantle in the Scythian Platform: the DOBRE-5 profile across the northwestern Black Sea and the Crimean Peninsula. Geophysical Journal International, 201, 406-428. https://doi.org/10.1093/ gji/ ggv018.

Stevenson, D. I. (1977). Hydrogen in the Earth's core. Nature, 268, 130-131. https://doi.org/10. 1038/268130a0.

Su, Q., Zeller, E., \& Angino, E. E. (1992). Inducing action of hydrogen migrating along faults on earthquakes. Acta Seismologica Sinica, 5(4), 841-847. https://doi.org/10.1007/BF02651032.

Sugisaki, R., Anno, H., Adashi, M., \& Ui, H. (1980). Geochemical features of gases and rocks along active faults. Geochemical Journal, 14(3), 101112. https://doi.org/10.2343/ geochemj.14.101.

Sukhanova, N. I., Trofimov, S. Y., Polyanskaya, L. M., Larin, N. V., \& Larin, V. N. (2013). Changes in the humus status and the structure of the microbial biomass in hydrogen exhalation places. Pochvovedenie, (2), 1-11. https:// doi. org/10.7868/S0032180X13020147 (in Russian).

Syvorotkin, V. L. (2002). Deep Earth degassing and global catastrophes. Moscow: Geoinformtsentr, 250 p. (in Russian).

Takai, K., Gamo, T., Tsunogai, U., Nakayama, N., Hirayama, H., Nealson, K. H., \& Horikoshi, K. (2004). Geochemical and microbiological evidence for a hydrogen-based, hyper-thermophilic subsurface lithoautotrophic microbial ecosystem (Hyper SLIME) beneath an active deep sea hydrothermal field. Extremophiles, 8 , 269-282. https://doi.org/10.1007/s00792-0040386-3.

Tian, Z.-Z., Liu, J., Xia, Q.-K., Ingrin, J., Hao, Y.T., \& Christophe, D. (2016).Water concentration profiles in natural mantle orthopyroxenes: A geochronometer for long annealing of xenoliths within magma. Geology, 45, 87-90. https://doi.org/10.1130/G38620.1.

Tsvetkova, T. A., Bugaenko, I. V., \& Zaets, L. N. (2017).Seismic visualization of plumes and super-deep fluids in mantle under Ukraine. Geofizicheskiy Zhurnal, 39(4), 42-54. https://doi. org/10.24028/gzh.0203-3100.v39i4.2017.107506 (in Russian).

Tsvetkova, T. A., Bugaenko, I. V., \& Zaets, L. N. (2020). Speed structure of the mantle under the Dnieper-Donets depression and its surro- 
oudings. Pt. II. Geofizicheskiy Zhurnal, 42(3), 145-161. https://doi.org/10.24028/gzh.02033100.v42i3.2020.204706 (in Russian).

Turke, A., Nakamura, K., \& Bach, W. (2015). Palagonitization of basalt glass in the flanks of midocean ridges: implications for the bioenergetics of oceanic intracrustal ecosystems. Astrobiology, 15, 793 - 803. https://doi.org/10.1089/ ast.2014.1255.

Vovk, I. F. (1987). Radiolytic salt enrichment and brine in the crystalline basement of the East European platform, in Saline Water and Gases in Crystalline Rocks. Geological Association of Canada, Special Paper, 33, 197-210.

Wakita, H., Nakamura, V., Kita, I., Fujii, N., \& Notsu, K. (1980). Hydrogen release, new indicator of fault activity. Science, 210, 188-190. https:// doi.org/10.1126/science.210.4466.188.

Walshe, J. L. (2006). Degassing of hydrogen from the Earth's core and related phenomena of the system Earth. Geochimica et Cosmochimica Acta, 70(18), A684-A684. https://doi. org/10.1016/j.gca.2006.06.1490.

Wang, X. B., Ouyang, Z. Y., Zhuo, Sh. G., Zhang, M. F., Zheng, G. D., \& Wang, Y. L. (2014). Serpentinization, abiogenic organic compounds, and deep life.Science China Earth Sciences, 57(5), 878-887. https://doi.org/10.1007/ s11430-014-4821-8.

Ware, R. N., Roecken, C., \& Wyss, M. (1984). The detection and interpretation of hydrogen in fault gases. Pure and Applied Geophysics, 122(2-4), 392-402. https://doi.org/10.1007/B F00874607.

Warr, O., Guinta, T., Ballentine, Ch. J., \& Sherwood Lollar, B. (2019). Mechanisms and rates of $\mathrm{He}, \mathrm{Ar}$, and $\mathrm{H} 2$ production and accumulation in fracture fluids in Precambrian Shield environments. Chemical Geology, 530, 119322. http: doi.org/10.1016/j.chemgeo.2019.119322.

Worman, S. L., Pratson, L. F., Karson, J. A., \& Klein, E. M. (2016).Global rate and distribution of H2 gas produced by serpentinization within oceanic lithosphere. Geophysical Research Letters, 43, 6435 - 6443. http:doi.org/10.1002/ 2016 GL069066.

Zgonnik, V. (2020). The occurrence and geoscience of natural hydrogen: A comprehensive review. Earth-Science Reviews, 203, 103140. https://doi.org/10.1016/j.earscirev.2020.103140.

Zgonnik, V., Beaumont, V., Deville, E., Larin, N., Pillot, D., \& Farrell, K. M. (2015). Evidence for natural molecular hydrogen seepage associated with Carolina bays (surficial, ovoid depressions on the Atlantic Coastal Plain, Province of the USA). Progress in Earth and Planetary Sciences, 2,31. https://doi.org/10.1186/s40645015-0062-5.

Zhou, X., Du, J., Chen, Z., Cheng, J., Tang, Yi., Yang, L., Xie, C., Cui, Y., Liu, L., Yi, L, Yang, P., \& Li, Y. (2010). Geochemistry of soil gas in the seismic fault zone produced by the Wenchuan Ms 8.0 earthquake, southwestern China. Geochemical Transactions, 11, 5. https://doi.org /10.1186/1467-4866-11-5.

\section{Перспективи пошуку водневих родовищ в рифтогенних структурах платформ (на прикладі Аніпровсько-Аонецького авлакогену)}

\section{В. М. Шестопалов ${ }^{1,2}$, О. Ю. Аукін ${ }^{2}$, В. І. Старостенко ${ }^{3}$, О. М. Пономаренко ${ }^{4}$, Т. О. Цветкова ${ }^{3}$, I. А. Колябіна ${ }^{2}$, О. М. Макаренко ${ }^{1}$, О. В. Усенко ${ }^{3}$, О. А. Рудь А. Онопріенко ${ }^{6}$, В. Ю. Саприкін ${ }^{1}$, Р. Вардапелян ${ }^{7}, 2021$}

\footnotetext{
${ }^{1}$ Науково-інженерний центр радіогідрогеоекологічних полігонних досліджень НАН України, Київ, Україна

${ }^{2}$ Інститут геологічних наук НАН України, Київ, Україна ${ }^{3}$ Інститут геофізики ім. С. І. Субботіна НАН України, Київ, Україна ${ }^{4}$ Інститут геохімії, мінералогії та рудоутворення ім. М. П. Семененка НАН України, Київ, Україна
} 
${ }^{5}$ Інститут металофізики ім. Г. В. Курдюмова НАН України, Київ, Україна

${ }^{6}$ Фундація «Національного розвитку та інновацій», Київ, Україна

${ }^{7}$ Європейський центр з передачі знань і технологій, Брюсель, Бельгія

На прикладі Аніпровсько-Аонецького авлакогену, який знаходиться в південній частині Східноєвропейської платформи, показана перспективність виявлення промислових накопичень водню в рифтогенних структурах платформ. У межах Аніпровсько-Аонецької депресії геолого-геофізичними методами виділяється значна кількість розломів глибинного закладення і кільцевих структур вулканогенного і вибухового походження, які $є$ цікавими з точки зору виявлення підвищених накопичень водню. Можливі місця розташування найбільш перспективних зон концентрації водню в платформних умовах приурочені до розломів у рифтових системах $\mathrm{i}$ їх найближчого оточення, а також до вибухових і вулканогенних кільцевих структур з ознаками сучасної активізації. Перспективність району на детальному рівні досліджень визначається, крім зазначеного структурного співвідношення, також результатами аналізу комплексу геофізичних характеристик (теплових, сейсмічних, гравітаційних, електропровідності, магнітних) і відповідних геологічних і гідрогеологічних параметрів. За результатами вивчення геолого-геофізичних матеріалів, космознімків і польових робіт виділені території для проведення подальших більш детальних робіт у межах Срібненської і інших кільцевих структур, Південного прибортового розлому, Північного прибортового розлому. Також виділені території для першочергового вивчення та території другої черги. У межах цих територій ідентифіковані ділянки для початкового дослідження із застосуванням космознімків, газового випробування (водень, гелій, метан та ін.), першочергових геофізичних досліджень, з оцінкою проміжних колекторів і поріА-покришок. За їх результатами може бути проведено пробне неглибоке буріння і опробування в свердловинах. За сумою отриманих результатів і порівнянь даних вибираються ділянки для першочергового більш глибокого буріння і опробування. Як приклад польових робіт по оцінці дегазації $\mathrm{H}_{2}$ в локальній депресії наведені результати, отримані в 30 км на схід від Києва. За межами локальної депресії концентрації водню на глибинах від 0,45 до 1,5 м близькі до 0. Максимальні значення концентрації $\mathrm{H}_{2}$ (до 3500 ppm на глибині 1,5 м) характерні для точки, що знаходиться поблизу краю депресії.

Ключові слова: глибинний водень, вуглеводні, кільцеві структури, рифт, Срібненська структура, дегазація водню, родовища водню.

\title{
Перспективы поиска водородных месторождений в рифтогенных структурах платформ (на примере Анепровско-Аонецкого авлакогена)
}

\author{
В. М. Шестопалов ${ }^{1,2}$, А. Е. Аукин ${ }^{2}$, В. И. Старостенко ${ }^{3}$, А. Н. Пономаренко ${ }^{4}$, \\ Т. А. Цветкова ${ }^{3}$, И. А. Колябина ${ }^{2}$, А. Н. Макаренко ${ }^{1}$, О. В. Усенко ${ }^{3}$, А. А. Рудь \\ А. Оноприенко ${ }^{6}$, В. Ю. Сапрыкин ${ }^{1}$, Р. Вардапелян ${ }^{7}, 2021$
}

${ }^{1}$ Научно-инженерный центр радиогидрогеоэкологических полигонных исследований НАН Украины, Киев, Украина

${ }^{2}$ Институт геологических наук НАН Украины, Киев, Украина

${ }^{3}$ Институт геофизики им. С. И. Субботина НАН Украины, Киев, Украина

${ }^{4}$ Институт геохимии, минералогии и рудообразования им. М. П. Семененко НАН

Украины, Киев, Украина 
${ }^{5}$ Институт металлофизики им. Г. В. Курдюмова НАН Украины, Киев, Украина

${ }^{6}$ Фонд национального развития и инноваций, Киев, Украина

${ }^{7}$ Европейский центр по передаче знаний и технологий, Брюссель, Бельгия

На примере Анепровско-Аонецкого авлакогена, который расположен в южной части Восточно-Европейской платформы, показана перспективность обнаружения промышленных скоплений водорода в рифтогенных структурах платформ. В пределах Анепровско-Аонецкой депрессии геолого-геофизическими методами выделяется значительное количество разломов глубинного заложения и кольцевых структур вулканогенного и взрывного происхождения, представляющих интерес в отношении обнаружения повышенных скоплений водорода. Возможное местоположение наиболее перспективных зон концентрации водорода в платформенных условиях приурочено к разломам в рифтовых системах и их ближайшим окраинам, а также к взрывным и вулканогенным кольцевым структурам с признаками современной активизации. Перспективность района на детальном уровне исследований определяется, помимо указанного структурного соотношения, также анализом комплекса геофизических характеристик (тепловых, сейсмических, гравитационных, электропроводности, магнитных) и соответствующих геологических и гидрогеологических параметров. По результатам изучения геолого-геофизических материалов, космоснимков и полевых работ выделены территории для проведения дальнейших более детальных работ в пределах Сребненской и других кольцевых структур, Южного прибортового разлома, Северного прибортового разлома. Также выделены территории для первоочередного изучения и территории второй очереди. В пределах этих территорий идентифицированы участки для начального исследования с применением космоснимков, газового опробования (водород, гелий, метан и др.), первоочередных геофизических исследований, с оценкой промежуточных коллекторов и пород-покрышек. По их результатам может быть проведено пробное неглубокое бурение и опробование в скважинах. По сумме полученных результатов и сравнений данных выбираются участки для первоочередного более глубокого бурения и опробования. В качестве примера полевых работ по оценке дегазации $\mathrm{H}_{2}$ в локальной депрессии приведены результаты, полученные в 30 км восточнее Киева. За пределами локальной депрессии концентрации водорода на глубинах от 0,45 до 1,5 м близки к 0. Максимальные значения концентрации $\mathrm{H}_{2}$ (до 3500 ppm на глубине 1,5 ) характерны для точки, находящейся в депрессии.

Ключевые слова: глубинный водород, углеводороды, кольцевые структуры, рифт, Сребненская структура, дегазация водорода, месторождения водорода. 